\title{
PELATIHAN SERTIFIKASI HALAL SEBAGAI STRATEGI MEMBANGUN KEPERCAYAAN KONSUMEN BAGI MASYARAKAT DESA GADINGKULON, KECAMATAN DAU, KABUPATEN MALANG
}

\author{
Esy Nur Aisyah'), Maretha Ika Prajawati2), Didik Wahyudi ${ }^{3)}$ \\ ${ }_{1,2}$ Fakultas Ekonomi, UIN Maulana Malik Ibrahim Malang. \\ 1Email: esynuraisyah@pbs.uin-malang.ac.id \\ 2Email: maretha@uin-malang.ac.id \\ ${ }^{3}$ Fakultas Sains dan Teknologi, UIN Maulana Malik Ibrahim Malang. \\ 3Email: didik wahyudi@bio.uin.malang.ac.id
}

\begin{abstract}
This activity is motivated by the products of the Gadingkulon villagers who have low bargaining power, their lack of ability in packaging and selling products is also an obstacle. Besides, many business actors have not pocketed and are not sufficiently knowledgeable about halal certification from MUI for the products they produce, so they will find it difficult to market their products to souvenir centers, supermarkets, and other markets. Guaranteed halal products through halal product certificates will provide comfort, safety, safety, and certainty of the availability of halal products for people in consuming and using halal products and can increase added value for business actors to produce and sell halal products. Therefore, they need to be equipped with knowledge and training on halal certification steaming. This service activity consists of 4 stages, namely preparation, meeting, training, and monitoring and evaluation. The community service activities carried out in Gading Kulon Village, Dau District, Malang Regency are going well. The result of community service activities is that people who have joint products with the Halal Center of UIN Maulana Malik Ibrahim Malang help meet and identify all the requirements needed and will then be bridged by the Halal Center of UIN Maulana Malik Ibrahim Malang until the issuance of halal certificates.
\end{abstract}

Keywords: halal certificates, customer trust

\begin{abstract}
ABSTRAK
Kegiatan ini dilatabelakangi oleh produk warga desa Gadingkulon yang daya tawar yang rendah, kurangnya kemampuan mereka dalam pengemasan dan penjualan produk juga menjadi kendala. Selain itu, banyak pelaku usaha yang belum mengantongi dan belum cukup pengetahuan tentang sertifikasi halal dari MUI untuk produk yang dihasilkan, sehingga mereka akan kesulitan memasarakan produknya ke pusat oleh-oleh, ke supermarket dan pasar-pasar lainnya. Jaminan produk halal melalui sertifikat produk halal akan memberikan kenyamanan, kemananan, keselamatan dan kepastian ketersediaan produk halal bagi masyarakat di dalam mengkonsumsi dan menggunakan produk halal, serta dapat meningkatkan nilai tambah bagi pelaku usaha untuk memproduksi dan menjual produk halal Oleh karena itu, mereka perlu dibekali dengan pengetahuan dan pelatihan pengurusan sertifikasi halal. Kegiatan pengabdian ini terdiri dari 4 tahapan, yaitu persiapan, pemetean, pelatihan serta monitoring dan evaluasi. Kegiatan pengabdian yang dilakukan di Desa Gading Kulon, Kecamatan Dau, Kabupaten Malang berjalan dengan baik. Hasil kegiatan pengabdian adalah masyarakat yang memiliki produk bersama dengan Halal Centre UIN Maulana Malik Ibrahim Malang membantu memenuhi dan mengidentifikasi segala persyaratan yang dibutuhkan dan selanjutnya akan dijembatani oleh Halal Centre UIN Maulana Malik Ibrahim Malang sampai pada penerbitan sertifikat halal.
\end{abstract}

Kata kunci: sertifikasi halal, kepercayaan konsumen 


\section{PENDAHULUAN}

Gadingkulon adalah salah satu wilayah yang ebrada di Kecamatan Dau, Kabupaten Malang, Provinsi Jawa Timur. Desa Gading Kulon terdiri dari 3 Dusun, yaitu Dusun Krajan, Dusun Sempu dan Dusun Princi. Dengan luas wilayah $453 \mathrm{~km} 2$ dan jumlah penduduk sebanyak 3.676 jiwa. Rata rata mata pencaharian penduduk Gading Kulon adalah petani serta peternak. Komoditas unggulan di desa Gading Kulon adalah produk holtikultura yaitu jeruk. Lahan tanaman jeruk di Desa Gading Kulon adalah lahan yang terluas di daerah Kecamatan Dau. Selain tanaman holtikulutra, Desa Gading Kulon juga terkenal dengan pengelolaan air terjun di tengah hutan negara, sistem terasiring, pembibitan berbagai jenis tanaman, tanaman toga dan warung organik dari sumber lokal langsung dari lahan milik warga. Pembibitan berbagai jenis tanaman di Desa ini berfungsi sebagai pelstarian hutan untuk menutupi permukaan kulit bumi dalam rangka pelestarian sumber daya alam.

Selain jeruk, warga masyarakat di Desa Gading Kulon juga menghasilkan produk olahan yang biasa diperjual belikan. Produk tersebut antara lain jamu tradional, keripik keulit jeruk serta aneka produk olahan kerupuk. Namun sayangnya, produk yang dihasilkan oleh masyarakat Desa Gading Kulon masih dikuasai oleh pengepul. Masyarakat Desa Gading Kulon biasa menjual hasil produknya kepada pengepul dalam jumlah yang besar. Ada bebrapa masalah yang dihadapi oleh pelaku suaha di Desa Gading Kulon, antara lain lemahnya harga tawar, dan pada akhirnya para pengepullah yang menikmati keuntungan. Selain daya tawar yang rendah, kurangnya kemampuan mereka dalam pengemasan dan penjualan produk juga menjadi kendala. Selain itu, banyak pelaku usaha yang belum mengantongi dan belum cukup pengetahuan tentang sertifikasi halal dari MUI untuk produk yang dihasilkan, sehingga mereka akan kesulitan memasarakan produknya ke pusat oleh oleh, ke supermarket dan pasar pasar lainnya. Jaminan produk halal bukan hanya dinyatakan oleh produsen, tetapi harus melewati proses pemeriksaan dan assessment secara objektif oleh lemabga yang berwenang (Ilyas, 2017).

Jaminan produk halal melalui sertifikat produk halal akan memberikan kenyamanan, kemananan, keselamatan dan kepastian ketersediaan produk halal bagi masyarakat di dalam mengkonsumsi dan menggunakan produk halal serta dapat meningkatkan nilai tambah bagi pelaku usaha untuk memproduksi dan menjual produk halal (Syafrida, 2016). Bagi umat Muslim, memilih produk halal menajdi sebuah kewajiban yang bernilai ibadah (Faridah, 2019). Kebutuhan seorang muslin terhadap produk halal seharusnya didukung oleh jaminan halal. Konsumen akan banyak dirugikan dengan banyaknya produk tanpa label halal maupun keterangan non halal (Ramlan \& Nahrowi, 2014). Pada produk makanan, informasi mengenai halal bisa dilihat pada label atau logo yang dicantumkan pada kemasan. Jika produsen telah memasang logo halal, berarti produknya telah melalui proses audit yang panjang. Dengan ini berarti produsen telah memberikan jaminan bahwa produk mereka halal untuk dikonsumsi (Karimah, 2015). Pencantuman label halal sebagai sarana informasi dari produsen ke konsumen mengenai produk yang akan dijualnya, sehingga konsumen akan mengetahui 
abhan apa saja yang digunakan, termasuk bahan tambahan dalam kemasan (Wibowo \& Mandusari, 2018).

Label halal merupakan salah satu factor yang sangat penting di dalam pemasaran sebuah produk, selain logo ISO, informasi komposisi dan logo merek (Bulan dkk, 2017). Adanya label halal dapat membantu kampanye pemasaran yang efektif bagi produsen, sehingga pelabelan halal pada setiap produk yang beredar sudah menjadi keharusan. Oleh karena itu pendampingan dilakukan dalam rangka memberi pemahaman tentang perlunya pelaksanaan sertifikasi halal bagi pemilik produk sekaligus membantu dan memfasilitasi para produsen untuk melakukan sertifikasi halal dari produk ke LPPOM MUI. Prioritas program ini adalah pemberdayaan dan peningkatan kapasitas bagi produsen di Desa Gading Kulon dalam mendukung pula program pemerintah tentang halal tourism melaui pangan halal.

\section{METODE PELAKSANAAN}

Dalam melakukan kegiatan pendampingan kepada pelaku suaha di Desa gading Kulon dilakukan dengan beberapa tahapan, antara lain:

1. Tahap persiapan. Dalam tahap ini, persiapan dilakukan dengan melalukan survey lokasi, mengadakan FGD dengan pelaku usaha dan perangkat desa.

2. Tahap pemetaan. Setalah melakukan persiapan dan FGD dengan pelaku usaha dan perangkat desa, selanjutnya kami melakukan pemetaan terhadap potensi usaha, identifikasi usaha, jenis usaha yang memiliki prospek usaha yang berkembang.

3. Tahap pelatihan. Pada tahap pelatihan, yang dilakukan adalah memberikan edukasi tentang pentingnya sertifikasi halal sampai pada persayaratan apa saja yang diperlukan untuk mendapatkan sertifikal halal termasuk di dalamnya adalah mengikuti pelatihan Sistem Jaminan Halal yang diadakan oleh LPPOM.

4. Tahap Monitoring dan Evaluasi. Kegiatan monitoring dan evaluasi kami lakukan secara bertahap dengan berkomunikasi melalui media elektronik serta pertemuan rutin setiap 1 sekali selama 2 minggu untuk memastikan seluuh persyaratan terpenuhi dan untuk selanjutnya akan difasilitasi dan dijembatani oleh Halal Centre UIN Maulana Malik Ibrahim Malang.

\section{HASIL DAN PEMBAHASAN}

Kegiatan pengabdian masayarakat ini diawali dengan melakukan Focus Group Discussion (FGD) dengan masyarakat Desa Gading Kulon yang dikenal dengan kampung KB. Kampung KB merupakan istilah yang digunakan oleh BKKBN dalam upaya memberdayakan masyarakat dalam meningkatkan kualiats hidup keluarga dan masyarakat. Dalam kampung KB inilah kami bekerja sama dengan perangkat desa untuk mengidentifikasi produk dan usaha yang telah dimiliki oleh warga dan kendala apa yang mereka hadapi dalam menjalankan usaha. Dari FGD yang dilakukan, mereka lalu mengungkapkan bahwa banyak produk dari ibu ibu yang kusulitan menjual produknya yang selama ini ahnya dijual apda tingkat pengepul saja, salah satu kendalanya adalah belum memiliki sertifikasi halal. 
Tahapan selanjutnya adalah pemetaan. Setalah melakukan FGD dengan pelaku usaha dan perangkat desa, selanjutnya kami melakukan pemetaan terhadap potensi usaha, identifikasi usaha, jenis usaha yang memiliki prospek usaha yang berkembang. Adapun usaha yang dimiliki oleh Desa Gading Kulon adalah produk jamu tradisional , keripik kulit jeruk, keripik talas, keripiki pisang dan aneka kerupuk yang sebagain besar dihasilkan oleh ibu ibu.

Kegiatan selanjutnya adalah pelatihan. Pada tahap pelatihan, yang dilakukan adalah memberikan edukasi tentang pentingnya sertifikasi halal sampai pada persayaratan apa saja yang diperlukan untuk mendapatkan sertifikal halal termasuk di dalamnya adalah mengikuti pelatihan Sistem Jaminan Halal yang diadakan oleh LPPOM. Pada kegiatan ini dijabarkan pentingnya sertifikat halal bagi sebuah produk. Masyarakat Desa Gading Kulon belum paham tentang urgensi adanya sertifikat halal bagi produk, mereka selama ini hanya mengetahui bahwa apa yang diproduksinya akan bisa dijual ke pengepul dan mereka mendapatkan uang. Kami pun mengemukakan bahwa sertifikasi hala l akan memberikan jaminan kepada konsumen bahwa produk yang dikonsumsi telah memenuhi persayaratan halal menurut kaidah Islam. Kami meyakinkan kepada warga Desa Gading Kulon bahwa, jika produk yang dihasilkan memiliki sertifikat halal akan memberikan kenyamanan bagi konsumen. Bagi orang Muslim, ketentuan informasi halal tidaknya suatu produk merupakan hal yang sangat penting karena berhubungan dengan pelaksanaan syariat Islam seperti ditegaskan di dalam Al Quran. Sudah seharusnya, umat Muslim memiliki haknya untuk mengetahui halal atau tidaknya suatu produk. UU No 33 tahun 2014 tentang Jaminan produk Halal (JPH) mengungkapkan yang termasuk produk halal adalah barang/jasa yang terkait dengan makanan, minuman, obat, kosmetik, produk kimiawi, produk biologi, produk rekayasa genetik serta barang yang gunaan yang dipakai, digunakan dan dimanfaatkan oleh masyarakat. Disamping itu, produsen juga ditunut untuk memproduksi produk produk halal yang akan dikunsumsi oleh masyarakat (Wibowo dan Mandusari, 2018)

Sertifikasi halal akan menjadi modal utama untuk mendapatkan kepercayaan dan kesetiaan konsumen muslim. Dengan adanya sertifikasi halal akan menguntungkan dua sisi, baik sisi produsen maupun konsumen. Disisi produsen, akan mendapatkan kepercayaan dari konsumen. Disisi konsumen, akan merasa aman karena tidak melanggar syariat ketika mengkonsumsi makanan/produk yang halal. Sertifikasi halal adalah syarat mendapatakn zizin untuk mencantumkan label halal pada kemasan produk dari instansi pemerintah yang berwenang. Dengan didukung oleh pengemasan/packaging yang menarik, maka warag Desa Gading Kulon dapat menjual sendiri produk mereka lewat media sosial atau dijual ke pusat oleh oleh. Sehingga dengan label halal yang ada akan menambah nilai bagi produk yang akan dijual.

Tahap selanjutnya adalah monitoring dan evaluasi. Kegiatan monitoring dan evaluasi kami lakukan secara bertahap dengan berkomunikasi melalui media elektronik serta pertemuan rutin setiap 1 sekali selama 2 minggu untuk memastikan seluruh persyaratan terpenuhi. Waktu yang dibutuhkan untuk pengurursan sertifikasi ini mulai dari pendaftaran hingga sertifikat diterbitkan adalah 30-40 hari. Warga Desa Gading 
Kulon yang memiliki usaha lalu didiampingi. Kami bersama dengan Halal Centre UIN Maulana Malik Ibrahim Malang membantu memenuhi dan mengidentifikasi segala persyaratan yang dibutuhkan dan selanjutnya akan dijembatani oleh Halal Centre UIN Maulana Malik Ibrahim Malang sampai pada penerbitan sertifikat halal. Sertifikasi halal berlaku selama 4 tahun dan selama masa berlaku sertifikasi halal, BPJPH MUI sesekali akan melakukan inspeksi mendadak. Serta penting diketahui oleh produsen bahwa setelah habis masa berlaku, maka perlu dilakukan pengajuan sertifikasi lanjutan paling lambat 3 bulan sebelum amsa berlaku sertifikat halal berakhir.

\section{SIMPULAN}

Label halal yang terdapat pada kemasan produk memiliki hubungan terahdap keputusan pembelian produk makanan, hal ini mengandung makna bahwa keberadaan labelisasi halal pada produk akan memberikan nilai positif dan emnajdi peluang besar dalam mempengaruhi keputusan membeli oleh konsumen. Dengan didukung oleh pengemasan/packaging yang menarik, maka warag Desa Gading Kulon dapat menjual sendiri produk mereka lewat media sosial atau dijual ke pusat oleh oleh. Sehingga dengan label halal yang ada akan menambah nilai bagi produk yang akan dijual. Berdasarkan hasil pengabdian yang dilakukan, maka dapat disimpulkan bahwa pentingnya menumbuhkan kesadaran masyarakat Desa Gading Kulon untuk mencantumkan labelisasi halal pada produk yang akan dijualnya, sehingga diharapkan dengan adanya pelatihan ini, warga yang memiliki produk akan berantusias dalam mengurus sertifikasi halal untuk emnjadikan produknya memiliki nilai lebih daripada sebelumnya,

\section{UCAPAN TERIMA KASIH}

Kami selaku tim pengabdian mengucapkan terima kasih banyak kepada UIN Maulana Malik Ibrahim Malang melalui pembiayaan UIN Mengabdi bekerja sama dengan Halal Centre UIN Maulana Malik Ibrahim Malang. Kami juga mengucapkan terima kasih banyak kepada Bapak Kepala Desa Gading Kulon Kecamatan Dau, Kabupaten Malang dan perangkat desa yang telah memfasilitasi kegiatan ini, sehingga kegiatan ini dapat terlaksana dengan baik.

\section{DAFTAR RUJUKAN}

Bulan, T. P. L, Fazrin, K dan Rizal, M. (2017). Pengaruh Label Halal dan Bonus dalam Kemasan terhadap Keputusan Pembelian pada Produk Kinder Joy pada Masyarakat Kota Langsa. Jurnal manajemen dan Keuangan, 8(2).

Faridah, H. D. (2019). Sertifikasi Halal di Indoensia: Sejarah, Perkembangan dan Implementasi. Journal of Halal Product and Research, 2(2).

Ilyas, M. (2017). Sertifikasi dan labeliasai Produk Halal Perspektif Maslahat. Jurnal ALQadau, 4(2). 
Karimah, I. (2015). Perubahan Kewenangan Lembaga-lembaga yang Berwenang dalam proses Sertifikasi Halal. Journal of Islamic Law Studies, Sharia Journal, 1(1): 107131.

Ramlan dan Nahrowi. (2014). Sertifikasi Halal sebagai Peenrapan Etika Bisnis dalam Upaya Perlindungan bagi Konsumen Muslim. Ahkam, 14(1): 145-154.

Syafrida. (2016). Sertifikasi Halal pada Produk Makanan dan Minuman Memebri Perlindungan dan Kepastian Hukum Hak Hak Konsumen Muslim. ADIL: Jurnal Hukum, 7(2).

Wibowo, D. E dan Mandusari, B. D. (2018). Pengaruh Labelisasi Halal terhadap Keputusan Pembelian oleh Konsumen Muslim terhadap Produk Makanan Olahan di Kota Pekalongan. Indoensia Journal of Halal. ISSN: 2623-162X 